\title{
A Missense Mutation in the Mitochondrial Cytochrome $b$ Gene in a Revisited Case with Histiocytoid Cardiomyopathy
}

\author{
ANTONI L. ANDREU, NICOLETTA CHECCARELLI, SO IWATA, SARA SHANSKE, AND \\ SALVATORE DIMAURO
}

H. Houston Merritt Clinical Research Center for Muscular Dystrophy and Related Diseases [A.L.A., N.C., S.S., S.D.], Department of Neurology, Columbia College of Physicians and Surgeons, 10032 New York, NY, U.S.A.; Centre d'Investigacions en Bioquimica I Biologia Molecular [A.L.A.], Hospitals Vall d'Hebron, Barcelona, E-08035 Spain; and Department of Biochemistry [S.I.], Uppsala Universitet, Upssala, S-75123 Sweden

\begin{abstract}
ABS
We describe a pathogenic mutation in the mitochondrial
cytochrome $b$ gene in a patient with a multisystem disorder
presenting as histiocytoid cardiomyopathy in whom a defect of
ubiquinol cytochrome $c$ oxidoreductase of the electron transport
chain had been documented biochemically. The mutation, a G to
A transition at nucleotide 15498, results in the substitution of
glycine with aspartic acid at amino acid position 251 The muta-
tion, which is heteroplasmic and fulfills all accepted criteria for
pathogenicity, is likely to impair the function of the holoenzyme
as deduced from its effects on the crystal structure of ubiquinol
\end{abstract}
Histiocytoid cardiomyopathy, initially described in 1962 by Voth (1), has received various names including infantile xanthomatous cardiomyopathy (2), focal lipid cardiomyopathy (3), oncocytic cardiomyopathy (4), infantile cardiomyopathy with histiocytoid change (5), and foamy transformation of infancy (6), although the term histiocytoid cardiomyopathy is now generally accepted (12). This is a rare but distinctive disorder of infancy and childhood characterized by the presence of characteristic pale granular foamy histiocyte-like cells within the myocardium. It usually affects children younger than $2 \mathrm{y}$ of age, with a clear predominance of females over males. These infants present with dysrhythmia or cardiac arrest, and the clinical course is usually fulminant, sometimes simulating sudden infant death syndrome.

Approximately 61 cases of histiocytoid cardiomyopathy have been reported (1-31), but the etiology of this disorder is still unknown. It has been suggested that histiocytoid cardio-

Received January 26, 2000; accepted March 20, 2000.

Correspondence: Salvatore DiMauro, M.D., H. Houston Merritt Clinical Research Center for Muscular Dystrophy and Related Diseases, Department of Neurology, Columbia College of Physicians and Surgeons, 630 W. 168th St., Room 4-420, New York, NY 10032, U.S.A.

Supported by grants from the National Institutes of Health (PO1HD32062 and NS11766) and Spanish Fondo de Investigacion Sanitaria (FIS 00/0797). cytochrome $c$ oxidoreductase. This is the first molecular defect associated with histiocytoid cardiomyopathy. (Pediatr Res 48: 311-314, 2000)

\section{Abbreviations}

complex III, ubiquinol cytochrome $c$ oxidoreductase cyt $\boldsymbol{b}$, cytochrome $b$ mtDNA, mitochondrial DNA

RFLP, restriction length polymorphism nt, nucleotide myopathy may be due to an abnormality of cardiac development (31) or to a developmental disorder of the atrioventricular conduction system and of the Purkinje cells $(12,16,18)$.

In 1984, we reported an infant girl who died of cardiac arrest at age 4 wk who had typical clinical and pathologic features of histiocytoid cardiomyopathy but who also showed involvement of other organs including liver (hepatic steatosis) and kidney (acute tubular necrosis). Biochemical studies of cardiac muscle showed isolated complex III deficiency and marked defect of reducible cyt $b$, the only mtDNA-encoded subunit of complex III of the respiratory chain, suggesting that the disease was due to an inborn error of the electron transport chain (13). Our studies of this patient preceded the era of "mitochondrial genetics" that opened in 1988 (32), but, even after that date, we did not consider the possibility of an mtDNA defect because there was no evidence of maternal inheritance, which is one of the hallmarks of disorders associated with point mutations in mtDNA. In 1999, however, we noted that mutations in the cyt $b$ gene are often sporadic and can arise during embryogenesis, affecting a limited number of cells and resulting in tissuespecific phenotypes $(33,34)$.

These findings prompted us to revisit our case of histiocytoid cardiomyopathy and complex III deficiency. Although heart 
tissue was no longer available, we could analyze kidney and liver obtained at autopsy. Molecular genetic studies revealed a pathogenic mutation in the cyt $b$ gene of mtDNA that fulfills all accepted criteria for pathogenicity. This is the first molecular defect associated with histiocytoid cardiomyopathy.

\section{METHODS}

Total DNA was isolated by standard methods from liver and kidney obtained at autopsy. To sequence the cyt $b$ gene, a PCR fragment overlapping the entire cyt $b$ gene was obtained using the following set of primers: forward, nt 14680-14699, and reverse, 15991-15973 [numbers according to the Cambridge reference sequence (35)]. Direct sequencing of the PCR product was performed using eight internal primers (310 Automatic Sequencer, Perkin Elmer, CA, U.S.A.) according to the strategy we previously reported $(33,34,37)$. Because in the presence of a mismatched primer, the mutation creates a new restriction site for TaqI, this enzyme can be used in RFLP analysis for detection and quantitation of the mutation. A 92-bp fragment was amplified by PCR using the following set of primers: a mismatched 37-mer forward (nt 15461-15497, containing a $\mathrm{C}$ at nt 15496) and 20-mer reverse (nt 15552-15533). The PCR conditions were 30 cycles of denaturation at $94^{\circ} \mathrm{C}$ for $30 \mathrm{~s}$, annealing at $56^{\circ} \mathrm{C}$ for $45 \mathrm{~s}$, and extension at $72^{\circ} \mathrm{C}$ for 1 min. $\alpha^{32} \mathrm{P}$-dATP was added during the last PCR cycle to avoid the underestimation of the mutated mtDNA due to heteroduplex formation. PCR products were digested with TaqI, electrophoresed through a $12 \%$ nondenaturing polyacrylamide gel, and subjected to autoradiography.

\section{RESULTS}

Sequence analysis revealed four nt substitutions in the patient's cyt $b$ gene compared with the reference sequence. Three of them (T14766C, A15326G, and A15758G) were considered neutral polymorphisms based on previous reports $(36,37)$. The fourth mutation, G15498A, resulted in the substitution of an encoded glycine (GGC) with an aspartic acid (GAC) at position 251 of the amino acid sequence (Fig. 1A). RFLP analysis (Fig. $1 B$ ) showed that the mutation was heteroplasmic in both liver $(90 \%)$ and kidney $(82 \%)$.

\section{DISCUSSION}

The diagnosis of histiocytoid cardiomyopathy is based on the presence of histiocyte-like cells with foamy or granular cytoplasm in the myocardium. These pathognomonic cells are found mainly in the ventricles, although similar alterations have been described in the pericardium, endocardium, valves, and conduction system $(1,4,5,7,8,10-12,18,20,23)$. The muscular origin of the histiocytoid cells has been well established, as they show strong immunohistochemical reactivity for actin, desmin, and myoglobin, whereas they do not stain for markers of genuine histiocytes (CD68 and lysozyme) (9, 21, $22,30)$.

In most reported cases, electron microscopy showed intracellular aggregates of enlarged mitochondria with disoriented cristae, suggesting that the disorder may have a mitochondrial
(A)

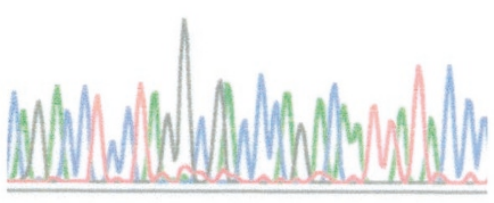

Control

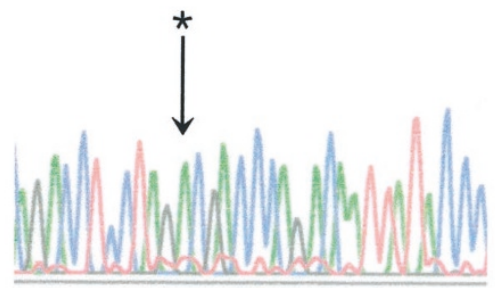

(B)

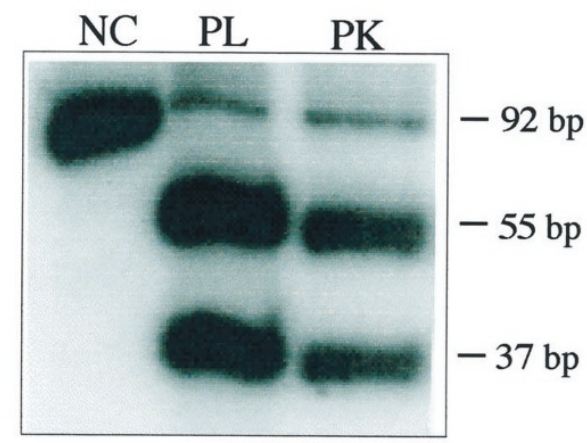

Figure 1. $(A)$ Electropherogram of the cyt $b$ gene showing the sequence of liver DNA in a control and in the patient. Sequencing was performed using a forward primer and shows $(\star)$ the G15498A transition. (B) RFLP analysis. Taq I cuts the original fragment (92 bp) into two fragments of 55 and $37 \mathrm{bp} . N C$ indicates normal control; $P L$, patient's liver; $P K$, patient's kidney.

origin $(2-7,9,13,16,18,23,25)$. A few reports offered even more convincing evidence of a mitochondrial etiology. Otani et al. (30) described a 15-mo-old girl with histiocytoid cardiomyopathy who also had hypotonia, lactic acidosis, and cytochrome $c$ oxidase-deficient fibers in the muscle biopsy. Although the authors did suggest an mtDNA origin for the disease, molecular genetic studies were not performed. In 1984, we described complex III deficiency and decreased reducible cyt $b$ in the patient revisited here, but, at that time, defects of mtDNA were not yet known. Until recently, point mutations in mtDNA were expected to be generalized and maternally inherited. This concept has now been revised because, in the past few years, several pathogenic mutations in protein-coding genes have broken the canonical laws of mitochondrial genetics. In particular, we and others have observed many mutations in the cyt $b$ gene that are neither generalized (they are only present in differentiated skeletal-muscle) nor maternally inherited (all cases were sporadic) $(33,34,39)$. Studies in cell culture suggest that these mutations arose as spontaneous events during embryogenesis. It seems reasonable to assume that mutations in the cyt $b$ gene can also arise in stem cell populations other than myoblasts, and this probably occurred in the present patient. 


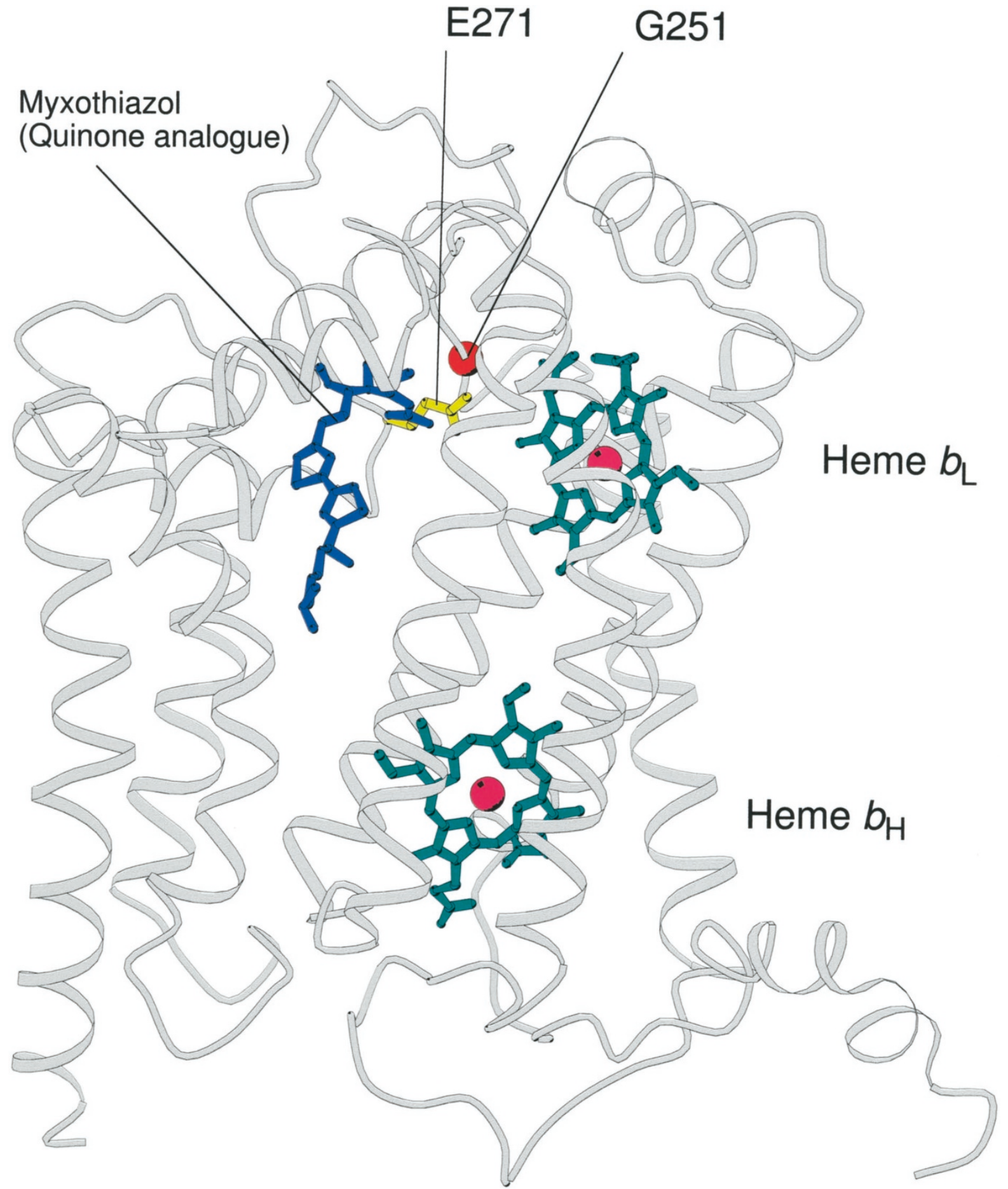

Figure 2. Crystal structure of the cyt $b$ protein. Hemes $b \mathrm{~L}$ and $b \mathrm{H}$ are shown (green). Amino acid $\mathrm{G} 251$ (which is mutated in the present patient) is in close contact with E271 (yellow), which is an amino acid in the domain 2 of the Qp site (ubiquinone-oxidation site) as determined by binding of quinone analogues (myxothiazol, dark blue). The mutation G251D would change the structure of the Qp site, impairing proton transfer.

Table 1. Evolutionary conservation of the cyt b protein

$\begin{array}{ll}\text { Patient } & \text { PDLLDDPDNY } \\ \text { Homo sapiens } & \text { PDLLGDPDNY } \\ \text { Beef } & \text { PDLLGDPDNY } \\ \text { Rabbit } & \text { PDLLGDPDNY } \\ \text { Chicken } & \text { PNLLGDPENF } \\ \text { Carp } & \text { PNLLGDPENF } \\ \text { Fly } & \text { PNLLGDPDNF } \\ \text { Yeast } & \text { PDTLGHPDNY }\end{array}$

Although heart tissue was not available for molecular genetic analysis, the mutation was found in liver and kidney, which were clinically and pathologically involved in this patient. We consider the G15498A mutation pathogenic for the following reasons.

1. This mutation was never reported as a neutral polymorphism despite extensive sequencing of the cyt $b$ gene in normal individuals from different ethnic backgrounds $(36,37)$. 
2. The mutation is consistent with the biochemical defect because the patient had both complex III deficiency and decreased amount of reducible cyt $b$ in heart tissue (13).

3. The mutation was heteroplasmic in both tissues analyzed, and heteroplasmy is a common feature of pathogenic mtDNA mutations.

4. The genetic defect was identified in liver and kidney, and both organs were affected (i.e. hepatic steatosis and acute tubular necrosis).

5. The mutation results in the replacement of a neutral amino acid (glycine) with an acidic one (aspartic acid) (G251D), a drastic change because glycine-251 is highly conserved throughout evolution (Table 1).

6. The effect of the replacement (G251D) on the crystal structure of complex III, which was described in 1998 (40), bolsters the pathogenic role of the G251D replacement. This residue is in close contact with the Qp site (one of the ubiquinone-binding sites of complex III) close to heme bL (Fig. 2). The presence of $D$ instead of $G$ should cause charge repulsion with E271, a residue at the Qp site. This, in turn, would change the structure of the Qp site and impair hydroquinone binding. As this site must be functional for proton transfer to occur, the mutation is likely to prevent proton transfer and to result in a partial block of the respiratory chain at complex III.

The G15498A mtDNA mutation is the first genetic abnormality identified in a patient with histiocytoid cardiomyopathy. Although this syndrome may be due to diverse etiologic factors, the presence of abnormal mitochondria in many reported cases and our present findings suggest that defects in mtDNA should be considered in patients with this disorder.

\section{REFERENCES}

1. Voth D 1962 Über die Arachnocytose des Herzmuskels. Frankf Z Pathol 71:646-656 2. MacMahon HE 1971 Infantile xanthomatous cardiomyopathy. Pediatrics 48:312-315

3. Bove KE, Schwartz DC 1973 Focal lipid cardiomyopathy in an infant with paroxysmal atrial tachycardia. Arch Pathol 95:26-36

4. Silver MM, Burns JE, Sethi RK, Rowe RD 1980 Oncocytic cardiomyopathy in an infant with oncocytosis in exocrine and endocrine glands. Hum Pathol 11:598-605

5. Ferrans VJ, McAllister HA, Haesse WH 1976 Infantile cardiomyopathy with histiocytoid change in cardiac muscle cells: report of six patients. Circulation 53:708-719

6. Yutani C, Imakita M, Ishibashi-Ueda H, Kamiya T, Aragaki Y 1985 A case of foamy myocardial transformation in infancy. Acta Pathol Jpn 35:1255-1265

7. Amini M, Bosman C, Marino B 1980 Histiocytoid cardiomyopathy in infancy: a new hypothesis? Chest 77:556-558

8. Bruton D, Hederson PB, Becroft DM 1977 Histiocytoid cardiomyopathy of infancy: an unexplained myofibre degeneration. Pathology 9:115-122

9. Gelb AB, Van Meter SH, Billingham ME, Berry GJ, Rouse RV 1993 Infantile histiocytoid cardiomyopathy-myocardial or conduction system hamartoma: what is the cell type involved? Hum Pathol 24:1226-1231

10. Koponen MA, Siegel RJ 1996 Histiocytoid cardiomyopathy and sudden death. Hum Pathol 27:420-423

11. MacGregor CG, Gibson A, Caves P 1984 Infantile cardiomyopathy with histiocytoid changes in cardiac muscle cells: successful surgical intervention and prolonged survival. Am J Cardiol 53:982-983

12. Malhotra V, Ferrans VJ, Virmani R 1994 Infantile histiocytoid cardiomyopathy: three cases and literature review. Am Heart J 128:1009-102
13. Papadimitriou A, Neustem HB, DiMauro S 1984 Histiocytoid cardiomyopathy in infancy: deficiency of reducible cytochrome $b$ in heart mitochondria. Pediatr Res 180:1023-1028

14. Prahlow JA, Teot LA 1993 Histiocytoid cardiomyopathy: case report and literature review. J Forensic Sci 38:1427-1435

15. Reid JD, Hadju SI, Attah E 1968 Infantile cardiomyopathy: a previously recognized type with histiocytoid reaction. Pediatrics 73:335-339

16. Zimmermann A, Diem P, Cottier H 1982 Congenital "histiocytoid" cardiomyopathy: evidence suggesting a developmental disorder of the Purkinje cell system of the heart. Virchows Archiv A Pathol Anat Histol 396:187-195

17. Cunningham NE, Stewart J 1985 A rare cause of cot death-infantile xanthomatous cardiomyopathy. Med Sci Law 25:149-152

18. Kauffman SL, Chandra N, Paress NS, Rodriguez-Torres R 1972 Idiopathic infantile cardiomyopathy with involvement of the conduction system. Am J Cardiol 30:648652

19. Kearney DL, Titus JL, Hawkins EP, Ott DA, Garson A 1987 Pathological features of myocardial hamartomas causing childhood tachyarrhythmias. Circulation 75:705-710

20. Ross C, Belton E 1968 A case of cardiac lipidosis. Br Heart J 30:726-728

21. Rossi L, Piffer R, Turolla E, Frigerio B, Coumel P, James TN 1985 Multifocal Purkinje-like tumor of the heart. Occurrence with other anatomic abnormalities in the atrioventricular junction of an infant with junctional tachycardia, Lown-GanongLevine syndrome, and sudden death. Chest 87:340-345

22. Ruszkiewicz AR, Vernon-Roberts E 1995 Sudden death in an infant due to histiocytoid cardiomyopathy. A light microscopic, ultrastructural, and immunohistochemical study. Am J Forensic Med Pathol 16:74-80

23. Saffitz JE, Ferrans VJ, Rodriguez ER, Lewis FR, Roberts WC 1983 Histiocytoid cardiomyopathy: a cause of sudden death in apparently healthy infants. Am J Cardiol 52:215-217

24. Suarez V, Fuggle WJ, Cameron AH, French AL, Hollingworth T 1987 Foamy myocardial transformation of infancy: an inherited disease. J Clin Pathol 40:329-334

25. Witzleben CL, Pinto M 1978 Foamy myocardial transformation of infancy: "lipid" or "histiocytoid" myocardiomyopathy. Arch Pathol Lab Med 102:306-311

26. Radford DJ, Chalk SM 1980 Infantile xanthomatous cardiomyopathy. Aust Paediatr J 16:123-125

27. Hubner G, Grantzow R 1983 Mitochondrial cardiomyopathy with involvement of skeletal muscles. Virchows Arch A Pathol Anat Histopathol 399:115-125

28. Heifetz SA, Faught PR, Bauman M 1995 Pathological case of the month. Histiocytoid (oncocytic) cardiomyopathy. Arch Pediatr Adolesc Med 149:464-465

29. Stahl J, Couper RT, Byard RW 1997 Oncocytic cardiomyopathy: a rare cause of unexpected early childhood death associated with fitting. Med Sci Law 37:84-87

30. Otani M, Hoshida H, Saji T, Matsuo N, Kawamura S 1995 Histiocytoid cardiomyopathy with hypotonia in an infant. Pathol Int 45:774-780

31. Boissy C, Chevalier A, Michiels JF, De Swarte M, Mariani R, Hofman P, Saint-Paul MC 1997 Histiocytoid cardiomyopathy: a case of sudden death in infancy. Pathol Res Pract 193:589-593

32. Wallace DC, Singh G, Lott MT, Hodge JA, Schurr S, Lezza AMS, Elsas II LJ, Nikoskelainen EK 1988 Mitochondrial DNA mutation associated with Leber's hereditary optic neuropathy. Science 242:1427-1430

33. Andreu AL, Bruno C, Shanske S, Shitlbans A, Hirano M, Krishna S, Hayward DA, Systrom RH, Brown RH, DiMauro S 1998 Missense mutation in the mtDNA cytochrome $b$ gene in a patient with myopathy. Neurology 51:1444-1447

34. Andreu AL, Bruno C, Dunne TC, Tanji K, Shanske S, Sue CM, Krishna S, Hadjigeorgiou GM, Shiltbans A, Bonilla E, DiMauro S 1999 A nonsense mutation (G15059A) in the cytochrome $b$ gene in a patient with exercise intolerance and myoglobinuria. Ann Neurol 45:123-130

35. Anderson S, Bankier AT, Barrell BG, de Brujin MHL, Coulson AR, Drouin J, Eperon EC, Nierlich DP, Roe BA, Sanger F, Schreier PH, Smith AJH, Staden R, Young EG 1981 Sequence and organization of the human mitochondrial genome. Nature 290:457-465

36. Kogelnik AM, Lott MT, Brown MD, Navathe SB, Wallace DC 1998 MITOMAP: a human mitochondrial genome database-1998 update. Nucleic Acid Res 26:112-115

37. Andreu AL, Bruno C, Hadjigeorgiou GM, Shanske S, DiMauro S 1999 Polymorphic variants in the human mitochondrial cytochrome $b$ gene. Mol Genet Metab 67:49-52

38. Kearney DL 1997 Critical commentary to: histiocytoid cardiomyopathy: a cause of sudden death in infancy. Pathol Res Pract 193:595-596

39. Andreu AL, Hanna MG, Reichmann H, Bruno C, Penn AS, Tanji K, Pallotti F, Iwata S, Bonilla E, Lach B, Morgan-Hughes JM, DiMauro S 1999 Exercise intolerance due to mutations in the cytochrome $b$ gene of mitochondrial DNA. N Engl J Med 341:1037-1044

40. Iwata S, Lee JW, Okada K, Lee JK, Iwata M, Rasmussen B, Link TA, Ramaswamy S, Jap BK 1998 Complete structure of the 11-subunit bovine mitochondrial cytochrome $b c 1$ complex. Science 281:64-71 